\title{
Anti-retroviral innate immune responses in multiple lymphoid tissues elicited by protective live attenuated SIV vaccination
}

\author{
Giada Mattiuzzo ${ }^{1 *}$, Claire Ham¹, Deborah Ferguson, Nicola Rose ${ }^{1}$, Martine Cranage ${ }^{2}$, Neil Almond ${ }^{1}$, Greg Towers ${ }^{3}$, \\ Neil Berry ${ }^{1 *}$
}

From Frontiers of Retrovirology 2011

Amsterdam, The Netherlands. 3-5 October 2011

\section{Background}

Vaccination with live attenuated SIV confers potent protection against wild-type challenge, although correlates of adaptive immunity have not been reliably demonstrated. Despite safety concerns for this vaccine approach in humans, understanding the mechanism of this protection may inform and guide HIV vaccine design. In Mauritian-origin cynomolgus macaques (Macaca fascicularis), we have demonstrated early, potent protection against the heterologous SIVsmE660 virus stock following vaccination with the minimally attenuated SIVmac251/C8 vaccine [1]. Failure to associate correlates of protection with adaptive immune responses and the emergence of protection as early as 3 weeks post vaccination has led us to characterise antiretroviral innate immune responses in this model system.

\section{Materials and methods}

The distribution and level of intracellular virus replication in multiple lymphoid tissues including the small and large intestine, spleen, inferior and superior mesenteric lymph nodes ( $\mathrm{i}$ and sMLN) was determined by quantitative PCR (qPCR) over a time-course of 3, 7, 10, 21 and 125 days following vaccination with live attenuated SIVmacC8. Virus presence in the same tissues was also confirmed by in-situ hybridisation. To evaluate aspects of the innate immune response, TRIM5 $\alpha$ genotype was determined and transcriptome analysis performed by qPCR for multiple ínterferon-inducing and induced genes including IRF-7, STAT-1, TRIM5 $\alpha$,

${ }^{1}$ HPA-NIBSC, Division of Retrovirology, Potters Bar, Herts, UK Full list of author information is available at the end of the article
ApoBEC3G, tetherin, TRIM-22. In addition, a range of immunological markers of cell-surface protein expression were measured by immunohistochemistry.

\section{Results}

Following SIV inoculation, rapid and widespread dissemination of virus was identified in multiple lymphoid tissues. The MLN represented the site with the most consistent frequency of virus infection, with virus detected at 3 days post-infection. Transcriptome analysis indicated a significant up-regulation of TRIM5 $\alpha$, ApoBEC3G and IRF-7 with the highest levels co-inciding with the peak of primary viraemia at day 10. Subsequently, responses tended to follow the control of acutephase replication beyond day 21 which remained above baseline levels at day 125. Retrospective analysis of protective vaccine studies indicates raised cell-surface markers of mediators of innate immunity including CD68+ macrophages, and S100 and DC-SIGN on dendritic cells which were upregulated and maintained in vaccinated, protected macaques but diminished in cases of retroviral superinfection.

\section{Conclusions}

These data suggest a broad anti-retroviral innate response generated during primary SIV infection, driven in this instance by live retrovirus vaccination with a nefdisrupted virus. These appear to be playing a role in controlling the vaccine virus, co-incident with widespread changes in cell-population dynamics previously described for this vaccine [2] which are maintained above basal levels by a persistent virus replicating in multiple lymphoid tissues. The relative contribution of 
these responses in vaccine protection is being investigated.

\section{Author details}

${ }^{1}$ HPA-NIBSC, Division of Retrovirology, Potters Bar, Herts, UK. ${ }^{2}$ St George's, University of London, Centre for Infection and Immunity, London, UK. ${ }^{3} \mathrm{MRC}$ Centre for Medical Molecular Virology, Division of Infection and Immunity, University College London, Cruciform Building, London, UK.

Published: 3 October 2011

\section{References}

1. Berry N, Ham C, Mee E, Rose N, Mattiuzzo G, Jenkins A, Page M, Elsley W, Robinson M, Smith D, Ferguson D, Towers G, Almond N, Stebbings R: Early Potent Protection against Heterologous SIVsmE660 Challenge Following Live Attenuated SIV Vaccination in Mauritian Cynomolgus Macaques. PLOS ONE 2011.

2. Li B, Berry N, Ham C, Ferguson D, Smith D, Hall J, Page M, QuarteyPapafio R, Elsley W, Robinson M, Almond N, Stebbings R: Vaccination with live attenuated simian immunodeficiency virus causes dynamic changes in intestinal CD4+CCR5+T cells. Retrovirology 2011, 3:8.

doi:10.1186/1742-4690-8-S2-029

Cite this article as: Mattiuzzo et al: Anti-retroviral innate immune responses in multiple lymphoid tissues elicited by protective live attenuated SIV vaccination. Retrovirology 2011 8(Suppl 2):029.

\section{Submit your next manuscript to BioMed Central} and take full advantage of:

- Convenient online submission

- Thorough peer review

- No space constraints or color figure charges

- Immediate publication on acceptance

- Inclusion in PubMed, CAS, Scopus and Google Scholar

- Research which is freely available for redistribution

Submit your manuscript at www.biomedcentral.com/submit 